\title{
Huckleberry Finn's "I'll go to hell”
}

\author{
Wenjie Zhang \\ Faculty of English, Zhejiang Yuexiu University of Foreign Languages, Shaoxing 312000, China \\ Paperiset@163.com
}

Keywords: Black slavery, The adventures of Huckleberry Finn, Racial equality.

\begin{abstract}
Mark Twain is considered father of modern American literature. The Adventures of Huckleberry Finn, published in 1884, his masterpiece, depicts adventures of Huck a white little boy and Jim a black slave down the Mississippi River to seek freedom. It reflects American social life in $19^{\text {th }}$ century. This paper makes an analysis of the historical background, the image of black slave Jim and Uncle Tom, the artistic and social value of the work from the following points:(1) the process of change of Huck's biases towards Jim the black. (2) The historical background of American racial relations. (3) The humanism and Mark Twain's appeal for racial equality reflected in the novel and the role the book played in American history in contributing to sound legal system.
\end{abstract}

\section{Introduction}

Mark Twain, the pseudonym of Samuel Langhorne Clemens, is considered father of modern American literature. By the last year of his life the literary reputation of Samuel Clemens had risen from the lowly status of a mere funny man to that of a major figure in the eyes of some initiated critics. Such for instance was the opinion of professor of Phelps of Yale, who wrote: "indeed, it seems to me that Mark Twain is our foremost living American writer”. In 1904, professor Richard Burton stated: “we possessed one living writer of indisputable genius...Mark Twain”[1]. In 1935, twenty-five years after Mark Twain's death ,Ernest Hemingway said “all modern American literature comes from one book by Mark Twain called Huckleberry Finn ... All American writing comes from that: there was nothing before. there has been nothing as good since."

The Adventures of Huckleberry Finn is Mark Twain's masterpiece. It was said that Mark Twain began this “ another boy's book” after the publication of The Adventures of Tom Sawyer in July 1876 and finished it in 1883.The book tells us a story before Civil War around 1850s in South America. The story can be briefly summarized as follows: Huck, a little uneducated white boy who escapes from his home for fear of his father's maltreatment meets with Jim an ignorant runaway black slave who flees there for fear of being sold by his owner Miss Watson. They raft down the Mississippi River to seek freedom. Huck and Jim meet with different kinds of people such as bandits and swindlers, slaves, etc and has experienced a lot of things and have been in and out of danger and trouble for many times. Finally, Jim gets freedom with the help of Huck and Tom Sawyer. Consensus has been reached by literary critics that the novel claims its importance in history of American literature by its vernacular and humorous language. This paper applies the theory of literary criticism to analyze the social value that Mark Twain calls for freedom and racial equality by presenting Huck the white boy breaks through the social discrimination and decides to regard Jim the black as a free humane being and help him get freedom.

\section{Huck Feels Guilty in Helping Jim}

The novel begins where The Adventures of Tom Sawyer ends, Huck, a white boy, flees to Jackson's Island to escape from his father's maltreatment. Old Jim also flees there in order not to be sold by his owner Miss Watson. They meet with each other and decide to raft down the Mississippi River. During their escape down the Mississippi River. Huck, in the beginning influenced by the social prejudices against the black people., is not kind to Jim and behaves arrogantly and even sneers at Jim only because Jim is a black. A good illustration of this is the conversation between Huck and Aunt Sally 
after the explosion on the River. Aunt Sally asks whether anybody had been hurt, “ no'm killed a nigger.” is Huck's reply. Another illustration is that for many times Huck feels guilty in helping Jim to escape even when Huck tears the letter into pieces making up his mind to save Jim which is considered by Huck to be awful thoughts.

\section{Huck' s Inner Struggle}

Huck's thoughts and attitude towards Jim the black changes little by little. Much of the book is concerned about Huck's inner struggle between the sense of guilt in helping Jim to escape and his profound conviction that Jim is a human being[2]. Huck's sense of guilt is also reflected in the following sentence "I would get all around, that Huck Finn helped a nigger to get his freedom; and if I was to see anybody from that town again, I'd be ready to get down and lick his boots for shame"[3]. Why Huck starts by believing that blacks are by nature lower than whites? Because Huck is taught and influenced by the people to believe so although Huck has received little education. the biggest social problem before Civil War in United States, especially in South US is black slavery, the deeply rooted prejudices and ingrained biases towards the black people.. Huck is a good boy in that he is brave, kind-hearted, clever and compassionate. But Huck's good virtue in himself can not change his social discrimination against Jim the black.

There are two occasions in the novel that Huck's inner struggle is highly depicted with emphasis. One is in Chapter 31. Huck decides not to tell on Jim black and tears the letter he has written to Miss Watson into pieces saying “ I'll go to hell!”. We have already discussed that in this paper. Another occasion is in Chapter 16. Huck flees to Jackson's Island and meets with Jim the black there, who flees there to escape from being sold by his owner Miss Watson. And they make the decision to raft down the Mississippi River to go to city Cairo to seek freedom. Old Jim is very happy and eager to get freedom and says he'll become a free man in a minute. But Huck is frustrated by Jim's happiness and strong desire to get freedom. Old Jim's happiness and delight is reflected in the following sentence "Jim said it made him all over trembly and fervish to be so close to freedom. And " he was saying how the first he would do when he got to a free state he would go to saving up money and never spent a single cent, and when he got enough he would buy his wife, which was owned on a farm close to where Miss Watson lived; and then they would both work to buy the two children, and if their master wouldn't sell them, they'd get an abolitionist to go and steal them”. But Huck gets nervous when hearing what Jim said and feels a sense of guilt. Huck's feeling is reflected in the following sentence "well I can tell you it made me all over trembly and fervish, too, to hear him, because I begun to get it through my head that he was most free-and who was to blame it". And in " every time he (Jim) danced around and says 'Dash's Cairo!' it went through me like a shot and thought if it was Cairo I reckoned I would die of miserable ness". After bitter inner struggle, Huck decides to tell on Jim and becomes happy as reflected in "I felt easy and happy, and light as a feather; right off all my troubles was gone". And right at that time, Huck and Jim meet with two man with guns who were chasing and searching for the five runaway slaves. When it comes to the real choice, Huck gives up. Huck saves Jim by telling the two men that Jim is Huck's father and has got smallpox aboard. Huck's feeling is mixed and perplexed when making this decision. We can see from the book that Huck saves Jim with a feeling of unwillingness and after he did, he felt a sense of guilt as reflected in the following sentence“ they went off, and I got aboard the raft, felling bad and low, because I knew very well I had down wrong...”.

On the other hand, Jim is also a brave and kind-hearted boy like Huck. old Jim is always kind and friendly to Huck as stated in Chapter 31 of the novel "But I couldn't seem to struck no place to harden me against him, but only the other kind ". So Huck sees few bad points of Jim and he sees many good points such as " I' d see him standing on my watch on top of the fog and when I came to him again in the swamp, up there where the feud was; as such like times; and would always call me honey, and pet me..."and such as when Huck helps and saves Jim in Chapter 16 of the novel that by telling the two men with guns who were chasing and searching for the five runaway slaves that Jim has smallpox aboard .Jim is so grateful to Huck that and says Huck is the best friend he has ever had in the world. 
All these things assure Huck that Jim is a human being-one of the best ,one point of fact that he had ever known.

\section{Huck Accepts Jim as a Loyal Friend}

Through series of episodes strengthening Huck's awareness of Jim as an individual and good boy, Huck progresses from uncritical acceptance of traditional attitudes and morals to an independent moral stance in direct defiance of social conventions[4]. Huck chooses to join his father and the royalty in hell. In Chapter 31 of the novel Huck writes Miss Watson, Jim's master a letter to tell her Jim's whereabouts to get Jim back and tears the letter into pieces, changes his mind saying " I'll go to hell!”.So it is a long process for Huck to cut through the social prejudices and social discriminations to accept Jim as a loyal friend. Huck's virtues come from his good heart and his sense of humanity. Huck is great and golden because he lives in a society in which maltreatment of black exists but he finally helps Jim get freedom, which is considered to be rebellious in the light of attitude at that time. when making friends with black people is considered to be against the law for the white. So it is not a decision easily to be made by Huck and Huck is great in this point and Huck is golden.

\section{Jim Becomes a Free Man}

The American racial discrimination and black slavery plays an important role in this novel. Without it there will be no such a great novel. The American racial discrimination is the key issue and trigger of the whole story. Most critics agree that Huck's moral development provides the novel's central theme [5]. Had Jim been a white man, people probably have forgotten the novel. Because Jim is in fact, finally free because his owner Miss Watson dies and frees him in her will. As we have stated that after Huck fakes his own death, real death is everywhere: with the murderous bandits aboard the Walter Scott, in the floating house, at the Grangerford-Shepherdson feud. Huck and Jim are together, which makes the danger of death inevitable and inescapable. Huck and Jim has to face the force of brutality of adverse environment at the same time Jim has to face another force: the black slavery. So Jim is facing much more danger of death than Huck in that Jim is a black.

As a matter of fact, the story takes place along the Mississippi River, on both sides of which there was unpopulated wilderness and a dense forest, before Civil War around 1850. The society was full of violence at that time. Many American people are adventuring west and south to search for treasure and gold. But the westward expansion was tears and starvation to black people like Jim. People were half wild and half civilized, many of whom are coarse, vulgar, and brutal. The biggest social problem at that time is black slavery, which are deeply rooted prejudices and ingrained biases towards the black before the Civil War in America. As American anti-slavery movement leader Frederick Douglas has said in 1852"...there are seventy-two crimes in the state of Virginia which; if committed by a black man (no matter how ignorant he be), subject him to the punishment of death; while only two of the same crimes will subject a white man to the like punishment, what is this but the acknowledgement that the slave is a moral, intellectual, and responsible being? The manhood of the slave is conceded. It is admitted that in the fact southern statute books are covered with enactments forbidding, under severe fines and penalties, the teaching of slave to read or to write " [6]. As a matter of fact, the King and the Duke report Jim the black to get \$300 and Jim is caught and locked up in a hut outside Mr. Phelps's house, Huck and Tom dig a hole to save Jim. Miss Watson dies and leaves a will to Tom. As Tom says to Aunt Sally " old Miss Watson died two months ago, and she was ashamed she ever was gong to sell him down the river, and so said so; and she set him free in her will”. The author of this paper thinks Miss Watson is so great in this point. So Jim is in fact, finally free because his owner dies and frees him in her will, and it is finally a slaveholder who is presented as the true rescuer[7]. Huck also plays an important role in helping Jim get free.. Had it not been Huck who changed his prejudices against blacks during their adventures and saved Jim for many times, Jim would probably had been caught and sold down the River to other people and would probably have been suffering a lot continuously.

\section{Conclusion}


In conclusion, this paper probes into human nature by analyzing the process of Huck's change of attitude towards black slave Jim from holding deeply-rooted prejudice against Jim to considering him as faithful friend at the risk of "going to hell" and also the dutiful, long-suffering servant Uncle Tom faithful to his white master or mistress. Huck and Jim's journey is generally considered as a symbolic repudiation of the corrupt society of the Mississippi valley, and the novel as a whole is often regarded as a condemnation of civilization[8]. Huck's moral development demonstrates the novel's central theme. The novel helps readers understand American racial relations before the Civil War, around which is Huck's moral development revolved. Influenced by the social conventions and deeply-rooted prejudices against black people, Huck the white boy in the beginning holds biases towards Jim the black, but during their adventures down the Mississippi River, Huck's awareness of Jim as a free normal human being strengthens little by little. Finally, Huck decides to regard Jim as a good friend and help him get freedom. Huck is great in that he has cut through the social prejudices and social discrimination to accept Jim as loyal friend. Mark Twain is also great in that he calls for racial equality and freedom by presenting us the story. In a word, Huck is great and golden in that he has cut through the social prejudices and social discriminations to accept Jim as a loyal friend. Mark Twain is great because he calls for racial equality and freedom, and praises the good points of humanity, which is inspiring and enlightening.

\section{References}

[1] Long, E.Hudson. Mark Twain Handbook. (New York: Hendricks House, U.S.A.1957). p.404

[2] Y.X. Chang: A Survey of American Literature. (Nankai University Press, China 1990), p.183.

[3] Y.X. Li, and Y.X. Chang, ed: Selected Readings in American Literature. (Nankai University Press, China 1990). p.376

[4] Poupard, Dennis, ed. Twenith Literatury Criticism.Vol.12 (Detroit: Gale Research Company, 1984). p.350

[5] Poupard, Dennis, ed. Twenith Literatury Criticism.Vol.12 (Detroit: Gale Research Company, 1984). p.350

[6] Y.X. Chang: A Survey of American Literature. (Nankai University Press, China 1990), p.158.

[7] Poupard, Dennis, ed. Twenith Literatury Criticism.Vol.12 (Detroit: Gale Research Company, 1984). p.409

[8] Poupard, Dennis, ed. Twenith Literatury Criticism.Vol.12 (Detroit: Gale Research Company, 1984). p.350 